\title{
HUMAN EMBRYONIC STEM CELL RESEARGH: WHY THE DISCARDED- GREATED-DISTINCTION CANNOT BE BASED ON THE POTENTIALITY ARGUMENT
}

\section{KATRIEN DEVOLDER}

\begin{abstract}
Discussions about the use and derivation of pluripotent human embryonic stem cells are a stumbling block in developing public policy on stem cell research. On the one hand there is a broad consensus on the benefits of these cells for science and biomedicine; on the other hand there is the controversial issue of killing human embryos. I will focus on the compromise position that accepts research on spare embryos, but not on research embryos ('discarded-created-distinction', from now on $d$-c-d). I will point out that this viewpoint is hard to maintain. The main reason is that the 'revealed beliefs' of its defenders are inconsistent with their 'professed beliefs', more specifically with their main argument, i.e. the potentiality argument. I will point out that (1) the defenders of $d$-c-d actually grant a relative moral status to the human embryo, (2) this moral status is dependent on internal and external criteria of potentiality, (3) potentiality seen as a variable value that also depends on external criteria cannot justify $d-c-d$, and (4) an approach to human embryonic stem cell-research that would also allow the use of research embryos is more compatible with the feelings, attitudes and values of those who currently defend $d$-c-d and, therefore, could lead to a broader consensus and to actions that alleviate individual human suffering.
\end{abstract}




\section{INTRODUCTION}

Stem cells are unspecialised cells that have the capacity for unlimited or prolonged self-renewal, and for producing cells of one or several specific and differentiated types. Although stem cell research is still largely in the experimental stages, ${ }^{1}$ there is consensus that its prospects look very promising. They could be used for various purposes in basic science ${ }^{2}$ as well as for clinical applications, primarily for creating new therapies by stem cell culture and the control of differentiation. There are at present three main lines of research: ${ }^{3}$ (1) research on adult stem cells (ASCs) obtained from organs and tissues of organisms after birth, (2) research on embryonic stem cells (ESCs), derived from embryos produced by IVF, either in the context of fertility treatment (spare embryos) or embryos created solely for research purposes, and (3) research on ESCs obtained through somatic cell nuclear transfer $\left(\mathrm{SCNT}^{4}\right)$

${ }^{1}$ Health Council of the Netherlands. 2002. Stem cells for tissue repair; research on therapy using somatic and embryonic stem cells. The Hague: Health Council of the Netherlands: 14, 17. Some types of stem cells, such as those derived from bone marrow and skin, have already been used in therapies. Others are effectively being used in trials, for example foetal midbrain cells for Parkinson's disease, and pancreatic duct cells for diabetes. R. Lovell-Badge. The future for stem cell research. Nature 2001; 414: 88.

${ }^{2}$ Stem cells could be used (a) to gain a better understanding of the development process and the underlying mechanisms regulating stem cell growth, migration, purpose and differentiation in animals and humans, (b) to create better models of human diseases by using stem cells in laboratory animals, (c) to culture specific differentiated cell lines to be used for pharmacology studies and toxicology testing and to do research on the immunology of stem cells and (d) to learn about the functions of certain genes and proteins.

${ }^{3}$ Other lines of research make use of pluripotent stem cells from the gonads of aborted foetuses and somatic stem cells from foetal organs and tissues and from the umbilical cord blood. Scientists are also experimenting with parthenotes and stem cells from chimeras (e.g. creation of embryos from unfertilised eggs from macaques. B.A. Maher. The Stem Cell-Cloning Plot Thickens. The Scientist 2002; 16 (4): 19; N. Wade. Stem Cell Mixing May From Human-Mouse Hybrid. The NY Times $27^{\text {th }}$ Nov. 2002), hybrid embryos, i.e. mixtures of embryos that would ordinarily be discarded because of their low quality (G. Kolata. Hybrid Embryo Mixture May Offer New Source of Stem Cells For Study. The NY Times $4^{\text {th }}$ June 2002) and carcinoma cells (P.J. Donovan, J. Gearhart. The end of the beginning for pluripotent stem cells. Nature 2001; 414: 92-97).

${ }^{4}$ In therapeutic cloning, an embryo is created by introducing the nucleus of a somatic cell from the patient into an enucleated (donor)egg, so that, in the blastocyst stage (when the embryo is like a microscopic ball of about 100-200 cells), pluripotent cells that are genetically identical to the cells of the patient's body can be harvested from the inner cell mass and cultured. When they are introduced into the patient's body they will not be rejected as foreign. 
commonly designated therapeutic cloning. ${ }^{5}$ The latter are called research embryos. ${ }^{6}$

Embryonic stem cells are considered to be the most promising stem cells for work on certain specific therapeutic and research aims. ${ }^{7}$ They seem to be more easy to isolate, can be induced to divide relatively rapidly in the laboratory and, most importantly, they are pluripotent. This means that they can be expanded seemingly indefinitely in culture, maintain a normal karyotype and have the potential (theoretically) to generate any cell type in the body. ${ }^{8}$ This seems to be less true of ASCs. ${ }^{9}$ There is also a wealth of knowledge about the characteristics and potential of animal ESCs. Embryonic germ cells (EGCs) from the aborted foetus have pluripotent capacities as well, ${ }^{10}$ but these cells appear at a later stage of development, which makes them less practical to work with. 11

Discussions about the use and derivation of pluripotent hESCs are a stumbling block in developing public policy on stem cell research. ${ }^{12}$ On the one hand there is a large consensus on the potential advantages of these cells; on the other hand there is the controversial issue of killing human embryos. The embryo debate has become very topical again. It has been argued that therapeutic cloning is ethically more controversial ${ }^{13}$ than the use of

5 The President's Council on Bioethics uses instead the term 'cloning-forbiomedical-research'. So called reproductive cloning is referred to as 'cloningto-produce-children'. The President's Council on Bioethics. 2002. Human Cloning and Human Dignity: An Ethical Inquiry. Washington, D.C.: PBC.

6 Some people consider cells that result from SCNT not to be 'embryos'.

7 Health Council of the Netherlands, op. cit. note 1, 28; Lovell-Badge, op. cit. note $1,88-91$.

8 Donovan, Gearhart, op. cit. note 3.

9 Other difficulties with ASCs: (1) some adult tissues may not contain stem cells, (2) those that do are not always readily accessible, and (3) it is not yet proven whether the stem cells found in somatic tissue are truly stem cells and whether they can proliferate ex vivo.

${ }_{10}$ M.J. Shamblott, J. Axelman, I.W. Littlefield et al. Human embryonic germ cell derivatives express a broad range developmentally distinct markers and proliferate extensively in vitro. Proc. Natl. Acad. Sci. 2001; 1: 304-313.

${ }^{11}$ National Institutes of Health. 2002. Stem Cells: A Primer. Available at http://www.nih.gov/news/stemcell/primer.htm.

${ }_{12}$ The European Group on Ethics in Science and New Technologies to the European Commission. 2000. Adoption of an Opinion on Ethical Aspects of Human Stem Cell Research and Use. Paris: EGE, 15.

${ }^{13}$ Most advisory or regulatory bodies argue for a temporary ban on therapeutic cloning. See, for example, Health Council of the Netherlands, op. cit. note 1, 17; PCB, op. cit. note 5; EGE, op. cit. note 12, 16. In France, where it is forbidden to create research embryos by IVF, a majority of the CCNE is in favour of controlled authorization of engagement in therapeutic cloning, but there 
research embryos created by IVF, and that the use of stem cells from spare embryos is most widely accepted. We may ask ourselves what makes these methods of derivation so controversial and how it is that they can be placed in a sort of 'hierarchy of ethical acceptability'. Analysing this hierarchy is important because it may influence public policy ${ }^{14}$ and is reflected in a variety of political compromises concerning stem cell regulation. I will return to these points below.

\section{THREE POSITIONS ON HUMAN EMBRYONIC STEM CELL RESEARCH}

Regarding views on the use and derivation of hESCs, we can distinguish three main groups, two of which are diametrically opposed to each other:

First, there are the opponents of so-called destructive embryo research. They radically oppose research with hESCs. In their opinion, the embryo needs to be protected as a human being, a person from the moment of conception. Killing an embryo is like killing an innocent person and cannot be justified by any allegedly desirable consequences. I am not going to deal with their arguments in this paper. ${ }^{15}$

A second position, diametrically opposed to the first, claims that the early embryo deserves no more respect than any other isolated human tissue. In their opinion, embryos, regardless of their origins, may be used for scientific research on condition that the embryos used in the experiments will not later be implanted in the womb. ${ }^{16}$

Between these polar positions, there are a range of viewpoints which attempt to articulate at least some grounds for restraint in the use of hESCs. We could call this 'the intermediate position', because its advocates seem to search for a 'happy medium' between the two 'extreme' views. Most legislations, regulations

remains much resistance from a group which may not be dominant in number, but which apparently is given much consideration in policy decisions. Comité Consultatif National d'Ethique. 2000. Avis $N^{\circ} 67$ sur l'avant-projet de révision des lois de bioéthique. Paris. CCNE: 10.

${ }^{14}$ S. Holm. Going to the roots of the stem cell controversy. Bioethics 2002; 16(6): 506.

${ }^{15}$ I deal with their arguments in K. Devolder. The Embryonic Stem Cell Debate: Steered Toward Foregone Principles and Conclusions? in Human Embryonic Stem Cell Research: Asian Bioethical Reflections in Dialogue with the West. Shui Chuen Lee, ed. (at press). Dordrecht. Kluwer Academics Press.

${ }^{16}$ Unless, of course, the research has therapeutic value for the embryo itself, and thus for the person that will eventually result from it. 
and advices on ESC-research adopt this middle-position, which is clearly a compromise. It has two main versions which, from an ethical point of view, partly overlap. Stem cell policy in the US, for example, is based on the so-called 'use-derivationdistinction'. ${ }^{17}$ A moral distinction is made between the derivation of the SCs and thus the 'killing' of the embryo on the one hand, and the use of these cells for research on the other. The central issue here is to which extent the researchers who use the embryonic stem cells are morally responsible for killing these embryos. I will not deal with this version of the intermediate position in this paper. ${ }^{18}$ The compromise position I will focus on is based on the 'discarded-created-distinction' (d-c-d). People who defend this view make a moral difference between using spare embryos or research embryos. The latter is considered to be unethical.

\section{THE DISCARDED-CREATED-DISTINCTION}

I will focus on one version of the intermediate position, namely on those who defend the discarded-created-distinction, i.e. those who accept research on spare embryos, but disapprove, under all circumstances, of the creation of embryos solely for research (a view also shared by those who defend the use-derivationdistinction). In most European countries and ethics committees, this version of the intermediate position is being defended. It is thought to be very convincing by many people, because it seems to offer a 'happy medium', which could lead to ethical consensus. I want to point out that it is hard to find a theoretical justification for this viewpoint. The main reason is that there is inconsistency between the revealed beliefs (i.e. beliefs revealed by one's actions or omissions) of its defenders and their professed beliefs, more particularly their main argument, i.e. the potentiality argument. I will point out that the defenders of d-c-d, seemingly unknowingly, grant a relative moral status to the human embryo based on both internal and external criteria of potentiality. I will argue that potentiality seen as a variable value that takes others' intentions into account, cannot justify d-c-d. Finally, I will argue that an approach to hESC-research that accepts the creation of human embryos for research purposes is more compatible with the feelings and attitudes of the defenders of $d-c-d$ and with widely shared

17 R.M. Green. 2001. The Human Embryo Research Debates. New York. Oxford University Press: 156.

${ }^{18}$ For an evaluation of this argument, I refer to R.M. Green. Benefiting from 'evil'; an incipient moral problem in human stem cell research. Bioethics 2002; 16(6): 544-556. 
values and, therefore, could lead to a broader consensus and to actions that increase human well-being and alleviate individual human suffering.

\section{RESEARCH ON SPARE EMBRYOS: PROS}

The arguments put forward by the defenders of d-c-d to allow research on spare embryos are based on the following principles:

The principles of beneficence and nonmaleficence, ${ }^{19}$ which state that it is right to benefit people if we can, and wrong to harm them.

The principle of proportionality, ${ }^{20}$ as related to hESC-research, states that human embryos can only be used for research if this serves an important purpose, such as a major health interest. In its recommendations on stem cell research, the NBAC expressed it this way: "In our view, the potential benefits of the research outweigh the harms of the embryos that are destroyed in the research process". ${ }^{21}$

The principle of subsidiarity, ${ }^{22}$ related to hESC-research, states that the derivation of ESCs from spare embryos is only ethically justified if there is no suitable and less controversial alternative means of achieving the purpose of the research. Opponents of ESC-research, for example, claim that there are sufficient alternatives, including xenotransplants, EGCs and ASCs and that this proves the superfluity of hESCs. ${ }^{23}$ Others - including those who work with ASCs - have indicated that these sources can be valuable but don't eliminate the need for ESCs. They are arguing for the right to conduct research with all stem cell types. ${ }^{24}$

19 See for example National Bioethics Advisory Commission. 1999. Ethical Issues in Human Stem Cell Research. Vol. I. Rockville, Maryland. NBAC: iv. See also Commission of the European Communities. 2003. Commission Staff Working Paper: Report on Human Embryonic Stem Cell Research. Brussels. European Commission: 9 .

20 Ibid. See also Health Council of the Netherlands, op. cit. note 1, 46.

21 National Bioethics Advisory Commission, op. cit. note 19, 56.

22 Health Council of the Netherlands, op. cit. note 1, 46.

${ }^{23}$ For example, lobby groups in the USA, such as the Coalition of Americans for Research Ethics. At a US Senate hearing, this group passed out a flyer entitled: Current Clinical Use of Adult Stem cells to Help Human Patients. On the front it lists a dozen ailments, including auto-immune diseases, anaemia and cancer, all of which have been treated with stem cells derived from mature tissue. At the bottom, the flyer reads: "Other side of page: complete list of conditions for which embryonic stem cells are in clinical use to help human patients." The other side is blank. What the flyer says is true, but it is also misleading. Adult bone marrow cells have been used for more than a decade, whereas hESCs were isolated and cultured for the first time in 1998.

${ }^{24}$ G. Vogel. Can Adult Stem Cells Suffice? Science 2001; 292: 1820-1822; Health Council of the Netherlands, op. cit. note 1, 47. 
The principle of the avoidance of waste is expressed very clearly by President Bush in his speech on $8^{\text {th }}$ August 2001 on US stem cell policy: "If these [frozen spare embryos] are going to be destroyed anyway, shouldn't they be used for a greater good, for research that has the potential to save and improve other lives?" 25 Many argue that creating spare embryos is a 'side effect' of a procreation process and we should allow couples to donate them for good purposes instead of wasting their potential. It does not alter their final disposition. The underlying idea is that, other things being equal, it is better to do something good than to do nothing good, and that, following from this, it must be better to make good use of something than to allow it to be wasted. ${ }^{26}$

These are all valuable principles. Surely it is more ethical to help people, other things being equal, than to help no one. And surely the research has to serve an important purpose. But none of these principles is sufficient to justify d-c-d. If someone uses them, we know that they have no objection to the use of spare embryos, but it does not necessarily follow that they are against the creation of research embryos. It is, for example, perfectly possible to argue against the waste of spare embryos while at the same time considering the creation of embryos solely for research as ethically acceptable (on the condition that the same goal cannot be reached by the use of spare embryos). The same is true for the other principles. The question we have to ask ourselves is what exactly makes it unethical to create embryos solely for research. Why is doing research on research embryos from an ethical point of view 'worse' than research on spare embryos?

\section{THE CREATION OF RESEARCH EMBRYOS: CONS}

\section{The instrumentalisation of the embryo and the violation of human dignity}

The main argument put forward by the supporters of $d-c-d$ is that by the creation of research embryos we 'instrumentalise' human

25 President's Statement on Funding Stem Cell Research. Available at http://www.whitehouse.gov/news/releases/2001/08/20010809-2.html. President Bush, however, ultimately rejects the principle of the avoidance of waste. He banned federally funded labs from using frozen spare embryos as a source of new stem cells.

${ }^{26}$ J. Harris. 2002. The ethical use of human embryonic stem cells. In Proceedings of the Third International Conference of Bioethics: Ethics, Legal and Social Issues in Human Pluri-potent Stem Cells Experimentation. S.C. Lee, ed. National Central University. Chungli, Taiwan ROC: C-20. 


\section{KATRIEN DEVOLDER}

life, and, following from this, 'violate human dignity'. Creating embryos solely for research purposes is, according to this opinion, an act in which the embryo is not treated with the appropriate respect a form of human life is entitled to, because it is used merely as a means to an end.

In the opinion of the defenders of $\mathrm{d}-\mathrm{c}-\mathrm{d}$, the embryo merits respect as a form of human life, but the fact that they allow certain practices implies that they are, often unknowingly, convinced that its right to protection depends on other values and interests than the embryo's right to life. This is evidenced by the fact that they approve of the creation of spare embryos and research on them. If embryos are being created to help infertile people (or people who make use of pre-implantation genetic diagnosis), there is no good reason to forbid the creation of embryos to help ill or injured people. In both cases embryos are used as a means to alleviate human suffering and increase human well-being. Here again, the argument of instrumentalisation without further explanation is not sufficient to justify d-c-d. It is not a logical consequence that one opposes the use of research embryos. After all, one can agree that the embryo is instrumentalised in embryo research without disapproving of this.

\section{Instrumentality linked to moral status}

However, opponents of the creation of research embryos put forward the following reasoning: the creation of research embryos is morally wrong because "it goes against the ethical intuition that the act of creating an embryo for reproduction is respectful in a way that is commensurate with the moral status of embryos, while the act of creating an embryo for research is not". 27

What is meant by respectful in a way that is commensurate with the moral status of embryos? Which moral status do the supporters of $\mathrm{d}$ $\mathrm{c}-\mathrm{d}$ ascribe to the human embryo and why? It seems that, again, we cannot avoid the question of the moral status of the embryo.

\section{The moral status of the embryo according to the defenders of $d$-c-d}

The defenders of d-c-d do not fully consider the embryo as a person and are consequently of the opinion that we do not have

27 National Bioethics Advisory Commission, op. cit. note 19, 53. 
to treat and protect it as a person. ${ }^{28}$ This is evidenced by the fact that in countries where d-c-d is defended, the creation of spare embryos and research on them is allowed, and has even become common practice. ${ }^{29}$

The supporters of d-c-d do not consider the embryo to be a person, but are still of the opinion that it merits respect as a form of human life. Why?

\section{Symbolic value of the embryo}

Some say that because embryos have symbolic value they merit special respect. However, it is not really the embryo that is at issue here, but the impact of certain practices on our respect for human life ${ }^{30}$ (or on the 'sanctity of human life'). The relevant question related to this argument, is whether the creation of research embryos will weaken our communal respect for human life in some way that in vitro fertilization or the experimental use of spare embryos does not? ${ }^{31}$ I will not go deeper into this issue here, because I think the following argument is of greater importance, and is also more conducive to finding another valuable approach to the hESC-research that is more compatible with the attitudes of the people who are trying to search for a compromise between the aforementioned polar positions.

\section{The embryo as a potential person}

Another argument put forward very often by defenders of d-c-d is that embryos merit respect because they are "potential human

${ }^{28}$ Because early embryos are, in the intermediate view, not considered to be humans, they cannot be instrumentalised in the Kantian sense. According to Kant a person is a being, which through its self-awareness is an end in itself and which, consequently, can never be reduced to the mere status of a means. The characteristic human dignity that has been cited many times since Kant is not applicable to the embryo itself.

29 This is also evidenced by the reproductive behaviours of people who defend the intermediate viewpoint. Many early embryos are lost in 'normal reproduction'. An estimate for early embryo loss in normal, healthy women shows that between two-thirds and three-quarters of all the zygotes do not proceed to implant themselves in the womb. For references on the various sources of data concerning spontaneous early embryo-loss I refer to Green, op. cit. note 17, N 185 .

${ }^{30}$ Ibid., 81.

${ }^{31}$ For an analysis of the issue of the use of symbolic arguments against the creation of research embryos, I refer to D.S. Davis. The Kennedy Inst Ethics J1995; 5(4): 343-354. 
beings'. That is why they consider the creation of spare embryos, i.e. embryos created for procreation, to be 'more commensurate with their moral status'. This seems to express something which is intuitively certain and acceptable and which opens the way to ethical consensus. But the expression 'the embryo is a potential person' is vague. This is evidenced by its use to defend opposing views on embryo research. ${ }^{32}$ If one chooses to use it, one has to explain what is meant by it and why it can serve as an argument to defend a certain position. One cannot singularly appeal to the fact that an embryo could become a person to give the protection we give to humans. Since the development of SCNT, every somatic cell of the human body is, in this sense, a potential person. A necessary condition for the realization of this potential is the application of the nuclear transfer technique. ${ }^{33}$ Here we have come to a very important and useful aspect of the concept of potentiality: its conditions.

\section{THE POTENTIALITY ARGUMENT}

\section{Potentiality and its conditions}

The only thing on which everyone agrees concerning the meaning of 'potentiality' is that something that is potential is not actual, but can become actual under certain conditions. These conditions can depend on internal and external factors. With regard to the 'embryo as a potential person', the internal factors are the characteristics of the embryo itself (e.g. its genetic constitution, its developmental potential). The external factors could be both in the genesis of the embryo (e.g. the application of SCNT) as well as beyond (e.g. being chosen to be implanted in the womb, becoming a spare embryo, being aborted). The external conditions, related to intentions of people, can depend on internal conditions (we select an embryo because it has characteristics that make it more 'healthy' than another), but do not necessarily do

32 Some hold that the embryo, because it is a potential person, deserves our full moral respect and protection. The concept of 'potential person' is then used as a step in the argumentation for the prohibition of so called destructive embryo research. Others (e.g. CCNE) use the same expression to forbid embryo research, except under certain conditions, while some members of the Belgian Consultative Bioethics Committee use it to defend the legalization of embryo research.

${ }^{33}$ J. Savulescu. 2001. Should we Clone Human Beings? Cloning as a source of tissue transplantation. In Cloning: Responsible Science or Technomadness. M. Ruse and A. Sheppard, eds. New York. Prometheus Books: 220. 
so (they can be based on other intentions, e.g. a woman who does not want a child). The opponents of hESC-research only take into account the internal factors and are of the opinion that the moral status of the embryo can only be deduced from the characteristics of the embryo itself, i.e. from its ontological structure. ${ }^{34}$ They see the potentiality principle as purely interior. What matters is that 'in the normal course of events' the embryo develops into a person. Whether or not it will actually become one makes no difference for the protection we have to give it.

The defenders of $d-c-d$ also grant a moral status to the embryo on the basis of its internal characteristics - they consider the embryo to be more valuable than any other human tissue or cell - but in fact they also take into account the external factors of potentiality, based on people's intentions. If they do so, they cannot justify d-c-d on the basis of the potentiality argument. Let me explain.

\section{Potentiality dependent on internal and external conditions}

\section{Internal Conditions for Potentiality}

With regard to the genesis of the embryo and the internal conditions that have to be fulfilled in order to become a person, we may ask ourselves what is meant by 'potentiality'. If the defenders of d-c-d keep on stressing that the embryo has an intrinsic value, what exactly do they mean?

They generally mean that all human embryos have something in common, namely the biological and genetic constitution to develop into a human being. This is often reflected in the definition of an embryo; e.g. the Belgian Senate's Bill on Embryo Protection defines an embryo as a 'cell or cohesive system of cells with the capacity to develop into a human being'. ${ }^{35}$ Because of this potential, the argument goes, the embryo deserves special respect. There exist various interpretations of the concept of 'potentiality'. ${ }^{36}$ Some see it as an 'all-or-nothing' matter. Potentiality is then interpreted as the capacity to 'become' or to

${ }^{34}$ M. Reichlin. The argument from potential: a reappraisal. Bioethics 1997: 11(1): 1-23.

35 Belgian Chamber of Representatives. Dec 2002. Bill Concerning Research on Embryos In Vitro.

${ }^{36}$ I only mention the 'general' interpretations of potentiality. Going deeper into the variety of other interpretations and their nuances would lead me too far from the aim of this paper. 
'produce ${ }^{37}$ something, in virtue of the operation or expression of its inherent, physical properties, and given circumstances that make the operation or expression of these properties possible. ${ }^{38}$ Whether or not the embryo actually becomes a person, is not relevant to the protection we have to give it. The potential of the embryo cannot 'unfold' or diminish ${ }^{39}$ it can only be frustrated. ${ }^{40}$ A similar view is what we might call the possibility view in which the potentiality of an embryo to become a person is seen as the possibility that its development into a person will, or would under favourable conditions, occur in the future. ${ }^{41}$ Reason for protection are not the present potentialities, but future outcomes. ${ }^{42}$ Killing an embryo is not a violation of some right of the embryo, but of the person into which the embryo may develop. Others see potentiality as a matter of degree. They acknowledge a link between potential and (inherent) probability. ${ }^{43}$ The more probable it is that an embryo will become a person, the more protection it should get. We can distinguish certain factors playing a part in the probability that an embryo develops into a person, e.g. (1) the extent of resemblance to the human bodily form; (2) the

37 See for example S. Buckle who considers the potential to become as a specific case of the potential to produce. The former he defines as 'developmental potential': the power of an entity to undergo changes to itself. The entity preserves some form of individual identity. The potential to produce does not require that any form of identity be preserved, neither is its application limited to individuals. S. Buckle. 1990. Arguing from the potential. In Embryo Experimentation - Ethical, Legal and Social Issues. P. Singer, H. Kuhse, S. Buckle, K. Dawson, P. Kasimba. Victoria, Australia. Cambridge University Press: 90-180.

38 Ibid.

39 According to some, this inherent potential can be present not until a certain stage of development is reached. R. McCormick, for example, considers developmental individuation at day 14 as a marker line after which the embryo has to be fully protected.

${ }^{40}$ See for example M. Lockwood. Warnock versus Powell (and Harradine): when does potentiality count? Bioethics 1988; 2(3): 187-213. See also M. Reichlin who states that the nature of the embryo is decisive: it possesses from the moment of conception a perfect human nature. In W. Wolbert. The potentiality argument in the debate relating to the beginning of personhood. Human Reproduction and Genetic Ethics 2000; 6(2): 19-26.

${ }^{41}$ See for example Hare's argument of 'possibility for future change'. R.M. Hare. 1993. Essays on Bioethics. London. Oxford University Press: 85.

42 P. Singer, K. Dawson. IVF Technology and the argument from potential. In P. Singer (et al.), op. cit. note 37, 76-89. See also S. Buckle, op. cit. note 37.

43 See for example John Noonan in J.T. Noonan Jr. 1970. An almost absolute value in history. In The Morality of Abortion. J.T. Noonan Jr., ed. Cambridge, Mass. Harvard University Press. See also H.T. Engelhardt Jr. who understands potentiality in the sense of 'probability' and proposes not to speak of "X's being a potential Y", but "of its having a certain probability of developing into Y" instead. (In W. Wolbert, op. cit. note 40, 19). 
extent of independence or autonomy with respect to a particular environment (e.g. the womb); (3) the fact that the embryo has passed some critical and easily identifiable marker event(s) in its development (individuation, development of the spinal cord, brain activation, becoming a sentient being, etc.).

According to those who defend the gradual approach of potentiality $^{44}$ the value of an embryo increases gradually during the course of its development. Some of them have a single criterion approach, which means that they choose one of the aforementioned factors in according a moral status to the embryo. For example, one may be of the opinion that the embryo's potential depends on (1) and that, therefore, for example, a nine-week-old foetus has more value than a 4-week-old embryo, which then has more value than a six-day-old embryo. Others defend a multicriteria approach. ${ }^{45}$ They are of the opinion that a variety of criteria interact and work together to lead to a mounting sense of concern and ultimately to judgments of worthiness-ofprotection. According to them, in determining the status of an embryo or a foetus at a particular stage of development, we have to look at all these qualities and their interrelationships. The greater the number of criteria an embryo or foetus meets, the closer it comes to being fully protectable. This view has the advantage that it expresses what many people feel intuitively when one says that an eight-month-old foetus is already more human than a one-week-old embryo. There is after all a continuous, gradual development from the zygote to a foetus several months old and to the newborn baby and beyond, but we can hardly deny that major changes occur in the course of this development. ${ }^{46}$

44 Potentiality is not the only way to justify gradualism, but because the aim of this paper is restricted to the potentiality argument, I think it is unnecessary to mention all the other arguments.

${ }^{45}$ See for example R.M. Green in Green, op. cit. note 17. Mary Anne Warren also defends a "multi criterial" view of moral status. M.A. Warren. 1997. Moral Status: Obligations to Persons and Other Living Things. Oxford. Clarendon Press.

${ }^{46}$ Which status to accord to the 7-month-old foetus is another, and in my view, more difficult question. But this is not at issue here. I only want to point out here that a gradualist approach to the moral status of the embryo and the foetus has the advantage that it is compatible with the attitudes and feelings of many people and, therefore, may open the way to a broader consensus on the issue of hESC-research. (Even if two people accept the gradualist view, there may be differences in viewpoint concerning late termination of pregnancy, but they will have the same opinion on research on in vitro embryos). It would have better consequences than the current compromise position which disapproves of the creation of research embryos. 
But I don't want to analyse the various views on the intrinsic value of the embryo in this paper. My point is that, whatever the criteria are on which the defenders of $d-c-d$ attribute an intrinsic moral status to the embryo, the fact is that it is hard to justify a difference in moral status between both spare and research embryos on the basis of the aforementioned criteria of potentiality. Both have the 'intrinsic capacity' to develop into a person, and in both cases this capacity, i.e. this potentiality, will be frustrated when they are used for research. Furthermore, spare and research embryos have clearly as much or as little chance of becoming a human being. As much, because they both have the intrinsic possibility of developing into a person under favourable conditions (in both cases, however, this possibility is removed by human intervention and for research purposes ${ }^{47}$ ); and as little in the sense that both are in vitro embryos which cannot develop into a person without human intervention. ${ }^{48}$ With regard to the gradual view of potentiality, it suffices to say that both spare and research embryos score equally low on each of the aforementioned criteria related to probability.

Consequently, with regard to their intrinsic potential, there is no moral difference between spare and research embryos. So what can it mean if one says that the creation of spare embryos is more commensurate with the moral status of embryos?

\section{External Conditions for Potentiality: Procreation Project}

The following consideration may 'potentially' establish a large consensus among those who consider the creation and use of spare embryos as ethically acceptable. Whatever the human emotions and opinions in relation to the embryo or the foetus may be, as soon as it becomes a question of the procreation project of a parent couple or a single parent, the embryo is experienced as 'the expected child' from the beginning of the pregnancy or, in the case of IVF, of the creation of the embryo in vitro. As we know, the value people ascribe to the in vitro embryo is variable and rises considerably as soon as the embryo is actually used in a parental project and decreases when it is no longer used in such a project. They are then referred to as 'spare', 'surplus' or 'supernumerary'. This is also demonstrated by the fact that many people forget that a number of their embryos are still frozen or do not even answer fertility clinics when asked what should be done with their surplus

47 Analogue to Hare's view. R.M. Hare, op. cit. note 41, 88.

48 See also P. Singer and K. Dawson, op. cit. note 42. 
embryos. ${ }^{49}$ Thus it is not the embryo as such that will be the object of value, but the embryo that is intended to lead to the birth of the desired child. ${ }^{50}$ Couples or individuals who create spare embryos apparently believe that the enhanced chance of a successful pregnancy and of fulfilling their wish for a child outweighs the moral value of each of the embryos. ${ }^{51}$ This is a very important finding.

Consider the following thought experiment:

- If we created research embryos by SCNT in a country where reproductive cloning is allowed, we could grant them the status of potential persons. But then, for the sake of argument, we might propose making a random selection of the same percentage of spare embryos that become a human ${ }^{52}$ from the research embryos and donate them to infertile couples who need a donor embryo. The percentage of 'research embryos' that becomes a human would then be the same as that of the 'spare embryos' that do, so they would have had the same chance of becoming a person. ${ }^{53}$

Which argument would the supporters of $d-c-d$ put forward to prohibit this proposal. ${ }^{54}$

${ }^{49}$ K. Hammarberg \& E.K. Oke. 2000. The impact of changing legislation on couples with embryos frozen in excess of five years. $16^{\text {th }}$ Annual Meeting of the European Society for Human Reproduction and Embryology. Bologna, Italy (Abstract P-251).

${ }^{50}$ Worthiness-of-protection in such a situation should be understood mainly as the use of all possible means to facilitate the fertilization, implantation and further development of the embryo and the foetus, with a maximal guarantee for the quality of the expected child's life.

51 HFEA figures show that between August 1991 and March 1999, 53,497 embryos from IVF programs were donated for research compared to the 118 embryos created for research. Parliamentary Office of Science and Technology. Stem cell research. Postnote 2002; 174: 4.

52 In Belgium, 504 of the 14,407 frozen spare embryos become humans, i.e. $3.5 \%$. Oral information, P. Devroey. 1999. The fate of embryos in different cases. Symposium organised by the Special Interest Group on Ethics of the European Society of Human Reproduction and Embryology (ESHRE). Cryopreservation of Human Embryos. Brussels, AZ-VUB. To be correct you would need to donate more than $3.5 \%$ of the research embryos to infertile couples, since only a fraction implants and goes to term. But that is irrelevant for what I want to point out.

${ }^{53}$ For a similar line of reasoning see J. Savulescu. The embryonic stem cell lottery. Bioethics 2002; 16(6): 508-529.

54 It is important to know that a common practice in fertility clinics is that the creation of embryos for infertility treatment is not clearly separated from the decision to donate the spare embryos for research. Before they start the IVF treatment, couples have to decide on the destination of the embryos at the end of the treatment or storage period. 
I think they would not have a sound argument. This is because the defenders of d-c-d consider early embryos, precisely because of their low intrinsic value, as a 'group' and grant moral status to them insofar as there is a chance that one of them will become the desired child. A study of infertile couples in Belgium shows that $92 \%$ of those who freeze embryos as part of their fertility treatment approve of the eventual destruction of their surplus embryos. ${ }^{55}$ The findings of Australian studies show that fewer than $10 \%$ of the spare embryos are donated to infertile couples who need a donor embryo. ${ }^{56}$ Most of the embryos are discarded. ${ }^{57}$

One possible line of defence is: unlike a research embryo, a spare embryo has had a chance of becoming a person and we have therefore treated it with more respect than the research embryo. But this will not work either, because in the thought experiment considered here, spare and research embryos would have had the same chance of becoming a person.

Apparently, intentional parents are not of the opinion that the potential to become a human should be realized in every deliberately created embryo. ${ }^{58}$ Many people prefer their embryos to be used as a means for research, instead of giving them to other couples. Moreover, if they donate their spare embryos to other couples, their main motivation is often to help those people who are in the same unhappy situation as they were before the IVF treatment was successful. People may of course have feelings of respect towards each created embryo, because of their intrinsic potentiality, but that does not mean they cannot be used for good purposes. There are forms of respect and deference which are less absolute and which can have gradations. The respect one has for an entity does not exclude it, provided that a meaningful argument is presented, from being used as a resource for a goal which is believed to be important. (Research on cadavers, with

${ }^{55}$ Y. Englert. 1998. The Fate of Supernumerary embryos: What do Patients Think about It? In In Vitro Fertilisation in the 1990's: towards a medical, social and ethical evaluation. E. Hildth \& D. Mieth, eds. Aldershot. Ashgate: 227-232.

${ }_{56}$ Hammarberg and Oke, op. cit. note 49. G.T. Kovacs, S.A. Breheny \& J.D. Melinda. Embryo donation at an Australian university in-vitro fertilisation clinic: issues and outcomes. MJA 2003; 178(3): 127-129.

57 Oral information. A. Trounson. 2003. Human Embryonic Stem Cells. Lectures in Medicine. Embryonic Stem cells. Organised by the Belgian Faculties of Medicine. Faculty of Medicine and Pharmacy. Brussels.

58 The aforementioned examples show the feelings and attitudes of intentional parents, but they also reflect the revealed beliefs of people who defend $\mathrm{d}-\mathrm{c}-\mathrm{d}$, because they approve of these practices. (It is legal and there is, for example, no social disfavour towards people who have a child by IVF and/or opt for the (immediate) destruction of their spare embryos). 
the informed consent of the party in question and on the condition of respectful treatment, is entirely legitimate in most countries). Early embryonic tissue or cells are respected by ensuring that they are used with care in research that incorporates substantive values such as alleviation of human suffering. ESC-research can provide such values. Apparently, the defenders of d-c-d agree that the intrinsic value of the embryos needs to be balanced against other needs. Are these attitudes and feelings commensurate with the moral status of the embryo as a potential person? Yes, if this moral status is considered as variable and based on internal and external criteria for potentiality.

The finding that the defenders of $\mathrm{d}$-c-d in fact balance their feelings of respect towards the embryo against other values also shows that those who try to defend d-c-d by referring to the 'doctrine of double effect' have no sound argument. The doctrine of double effect argues that one may opt for an action B with negative consequences if it is impossible to opt for an obligatory action $\mathrm{A}$ without immediately opting for $\mathrm{B}$, and on the condition that (1) the negative consequences are less or equal to the positive consequences of $\mathrm{A}$ and (2) it is the consequences of $\mathrm{A}$ and not $\mathrm{B}$ which are intended. Applied to the issue of spare embryos, action A is the achievement of a pregnancy and action $\mathrm{B}$ is the obtaining of spare embryos. According to the doctrine of double effect, this would be justifiable if $A$ is intended and B not, and if $\mathrm{A}$ is impossible without having $\mathrm{B}$ as a consequence. In the case of spare embryos, these criteria are met. Action B is, however, 'making spare embryos' and not 'research on spare embryos'. Experimenting is merely a new action, let's say C, which must be justified on another basis. We have seen that the grounds on which the defenders of d-c-d appear to justify research on embryos is a consequentialist argument, namely that the respect we have with regard to the human embryo has to be balanced against other values and needs.

\section{Widely shared values}

Apart from the fact that an approach to hESC-research that allows the creation of research embryos seems compatible with the attitudes and feelings of the current defenders of d-c-d, this approach is also compatible with widely shared values, more precisely those on which they base their argument in favour of research on spare embryos (see above). An approach which allows research on both kinds of embryo complies with the principles of beneficence and non-maleficence. These principles are not applicable to early 
embryos because they are not sentient beings with consciousness or health. The principles, however, are relevant for the millions of people who suffer from any kind of disorder that can potentially be treated by hESC-based therapies. It is also compatible with the principles of subsidiarity and the avoidance of waste. These are applicable in the sense that one should use spare embryos before creating embryos for a specific purpose, (1) to avoid waste and (2) to use equally efficient means that are already available and are less ethically controversial. It is up to experts in this matter to come to a decision whether, and under which circumstances, well-defined research can be conducted with spare embryos, and to decide under which circumstances it is more appropriate or necessary to use research embryos. In the current state of stem cell research a majority of researchers already seems to acknowledge the need for experiments on both spare and research embryos. ${ }^{59}$ The principle of autonomy is applicable to the procedures of informed consent and to the right of individuals to hand over their own embryos, cells and tissues for scientific research. The advocates (if they are still so) of d-c-d often use the argument that many people disapprove of the use of research embryos, to strengthen their position. I think that, on the contrary, a view that allows the creation of research embryos has a chance of becoming accepted in a society that now defends d-cd. People's current sensibilities are not hurt, or a only little, when deliberately created embryos not involved in a parental project are donated for research. At least, certainly not to an extent that would outbalance the benefits for those people. Better information on the possibilities of hESC-research might positively influence people's opinion.

59 Any study that begins with gametes or that requires fertilization as an end point necessitates the use of research embryos (e.g. research on contraceptives, IVM, etc.). Another reason why research embryos are needed is that some studies, such as those on the role of certain drugs in birth defects and pediatric cancers, cannot be conducted without a control population of normal, healthy embryos. Many of the cryopreserved embryos have cytoplasmatic, chromosomal or nutritional deficiencies. Green, op. cit. note 17, 74-75. Moreover, research embryos are needed to study the proliferation and (de)differentiation process of stem cells. Controlling these processes is a necessary condition for working with ASCs. According to some, therapeutic cloning offers advantages that cannot be efficiently obtained by any other means. Here also research embryos are needed. 


\section{CONCLUSION}

The discarded-created-distinction cannot be maintained on the basis of the potentiality argument. It is my impression that some prominent people try to find a political solution and steer the debate to 'foregone principles and conclusions' 60 in order to convince as many people as possible. This results in forced philosophical constructions that slow down stem cell research.

I suggest we take into account the feelings and attitudes of advocates of d-c-d. Analysing these feelings and attitudes, it seems that in general a lot of people have respect and concern for some kind of protection for embryos and foetuses, but that these feelings seem to diminish when it comes to the early developmental stages and that they depend on whether or not an embryo is involved in a parental project. The main argument to defend dc-d, namely the fact that creating embryos for research is unethical because it is not commensurate with their moral status as potential humans, cannot hold good. I have pointed out that the expression 'potential person', applied without any distinction regarding the early embryo, is biased, because it does not account for various external factors, both in the genesis of the embryo as well as beyond it. I argued that the defenders of d-c-d grant a variable moral status to the human embryo, based on both internal and external conditions of potentiality. From this it follows that whatever their approach to the intrinsic potential of the human embryo is, since they let the value of an embryo depend on external criteria - of which the parental project is the one on which there seems to be a broad consensus - there are no good reasons for d-c-d. According to their view, both spare and research embryos are deliberately created embryos, with equally intrinsic potential, which are not included in a parental project. They deserve some respect, but they can be used for beneficial purposes. As soon as we allow the destruction of embryos, it does not really matter in which way they are conceived. Moreover, an intermediate view which grants intrinsic value to the embryo, but makes no moral difference between the use of research embryos and spare embryos, seems to be more compatible with the attitudes and feelings, and the revealed beliefs of the advocates of $\mathrm{d}-$ $\mathrm{c}-\mathrm{d}$ and with widely shared values. And, more importantly, such a

${ }^{60}$ See P.R. Wolpe \& G. McGee. 2001. 'Expert Bioethics' as Professional Discourse: The Case of Stem Cells. In The Human Embryonic Stem cell Debate. Science, Ethics, and Public Policy. S. Holland, K. Lebacqz \& L. Zoloth, eds. Cambridge, Massachusetts. MIT Press: 185-196. 


\section{KATRIEN DEVOLDER}

view allows stem cell research to progress, so that treatments can be developed that will increase human well-being and alleviate individual human suffering.

Katrien Devolder

Ghent University

Centre for Environmental Philosophy and Bioethics

Blandijnberg 2

B-9000 Gent

Belgium

katrien.devolder@rug.ac.be

Acknowledgments to Professor Freddy Mortier 